\title{
MEASUREMENT OF ZAKAT IMPACT ON BAITUL MAAL HIDAYATULLAH: EVIDENCE FROM INDONESIA
}

\author{
Abdullah Alkhosik Fathoni ${ }^{1}$, Efri Syamsul Bahri ${ }^{2}$, Mustafa Kamal ${ }^{3}$ \\ ${ }^{1,2,3}$ Sekolah Tinggi Ekonomi Islam SEBI, Indonesia
}

\begin{abstract}
Zakat is the third pillar of Islam that must be fulfilled by every Muslim who has a sufficient amount of zakat. The purpose of zakat management is to increase the benefits of zakat in creating social welfare and poverty alleviation. This study aims to measure the impact of zakat on the welfare of mustahiq using the Center of Islamic Business and Economic Studies (CIBEST) model. The research sample consisted of mustahiq households who received zakat funds from the Baitul Maal Hidayatullah Amil Zakat Institute (LAZ $B M H)$. Measuring the impact of zakat using the CIBEST model includes both material and spiritual aspects. The primary data were collected using a questionnaire. The results of the study found that the mustahiq household welfare index value increased by 11.5 per cent. In terms of material, productive zakat succeeded in reducing material poverty by 11.5 per cent. However, the zakat assistance provided does not have a significant effect on poverty alleviation. In the spiritual aspect, productive zakat can maintain mustahiq's spiritual stability. Therefore, as a form of accountability, both vertically and horizontally, to Allah SWT, the impact of zakat must be increased from both material and spiritual aspects.
\end{abstract}

Keywords: zakat impact, cibest model, mustahiq welfare, productive zakat.

*Corresponding author: email: efri.sb@ sebi.ac.id

Received: July 17, 2020; Accepted: May 09, 2021; Published: June 15, 2021

\begin{abstract}
Abstrak: Zakat merupakan rukun Islam ketiga yang harus dipenuhi oleh setiap muslim yang memiliki jumlah zakat yang cukup. Tujuan pengelolaan zakat adalah untuk meningkatkan manfaat zakat untuk mewujudkan kesejahteraan masyarakat dan pengentasan kemiskinan. Penelitian ini bertujuan untuk mengukur dampak zakat terhadap kesejahteraan mustahiq dengan menggunakan Model Center of Islamic Business and Economic Studies (CIBEST). Sampel penelitian adalah rumah tangga mustahiq penerima dana zakat dari Lembaga Amil Zakat Baitul Maal Hidayatullah (LAZ BMH). Pengukuran dampak zakat dengan Model CIBEST mencakup aspek material dan spiritual. Data primer dikumpulkan melalui kuesioner. Hasil penelitian menemukan bahwa nilai indeks kesejahteraan rumah tangga mustahiq mengalami peningkatan sebesar 11,5 persen. Dari segi materi, zakat produktif telah berhasil mengentaskan kemiskinan materi hingga 11,5.
\end{abstract}


Namun, bantuan zakat yang diberikan belum memberikan pengaruh yang signifikan terhadap pengentasan kemiskinan. Dalam aspek spiritual, zakat produktif dapat menjaga kondisi stabilitas spiritual mustahiq. Oleh karena itu, sebagai bentuk pertanggungjawaban baik secara vertikal kepada Allah SWT maupun secara horizontal kepada stakeholders, maka dampak zakat harus ditingkatkan baik dari aspek material maupun spiritual.

Kata kunci: dampak zakat, model cibest, kesejahteraan mustahiq, zakat produktif.

\section{INTRODUCTION}

According to Qardawi (1969), zakat is the third pillar of Islam that must be fulfilled by the Muslim community under the condition of achieving nisab. Riyaldi (2017) argues that zakat is a fundamental obligation in Islam. Septiandani and Shomad (2017) refer to zakat in terms of primary worship. From the aspect of Sharia, the command to collect zakat is stated in the Qur'an in At-Taubah verse 103. Meanwhile, the command to distribute zakat is also clearly stated in the Qur'an in At-Taubah verse 60. The Qur'an states that there are eight asnaf recipients of zakat: Fakir, Miskin, Amil, Mu'allaf, Riqab, Gharim, Fisabilillah, and Ibnu Sabil. Ahmed et al. (2017) explain that Sharia scholars continuously monitor the limits of the eight asnaf to adapt to the times.

According to As-Sayid Sabiq (1972), the language of zakat has several meanings, such as an-namaa (growth and development), ath-thaharatu (purity), al-barakah (blessing), katsrah al-khair (abundance of goodness), and ash-shalahu (correctness) (Ismail et al., 2018). Ismail et al. (2018) explained that zakat property would be a blessing, grow, develop, and increase, sacred, and add goodness. According to Ibn Taymiyyah, the hearts and property of people who pay zakat become pure, clean, and grow meaningfully (Chaniago, 2015).

In a recent article, Ganiyev and Umaraliev (2020) argued that the law of zakat existed at the time of the Prophet Muhammad. According to Yusuf and Derus (2013), zakat management has also been implemented since the ordination of zakat directly from the Prophet Allah (SAW). Several researchers, such as Aziz (2015), Hakim (2016), and Mujiatun (2018), stated that the management of zakat in Indonesia is carried out based on Law No. 23 of 2011 concerning zakat management. This regulation states that there are two purposes for zakat management. First, it increases the effectiveness and efficiency of services in managing zakat. The second goal is to use zakat management to increase the benefits of zakat to realize people's welfare and poverty alleviation.

The benefits of zakat felt by mustahiq can be seen from how much impact mustahiq feels like the beneficiary of zakat. The research results of Nafiah (2015) and Taufiq et al. (2018) found that productive zakat has a positive and significant effect on mustahiq. Meanwhile, the latest research by Khumaini (2019) found that productive zakat funds have a positive and insignificant effect on the welfare of people. Thus, there is a difference in the effect of productive zakat on mustahiq. The research results of Taufiq et al. (2018) also found that the assistance provided to mustahiq 
had a positive but insignificant effect. In a recent study, Kurniawan et al. (2020) found that mentoring had a positive and significant effect on the development of mustahiq micro businesses. It also shows that there are different results for different objects in this study.

In this research, the measurement of the impact of zakat is seen in the terminology of welfare. According to Kusuma et al. (2016), in Islam, welfare is defined as fulfilling the basic needs (dharuriyat) of every human being in society. According to Ilyas (2014), welfare is also called falah, which means holistic well-being from an Islamic perspective. Holistic, in this case, is a balance between the material and spiritual dimensions, individual-social, and welfare in the worldly and hereafter (Ilyas, 2014). Beik and Arsyianti (2016) argue that basic needs can be divided into two categories: basic and basic. To measure the fulfilment of these basic needs, Beik and Arsyianti (2016) built the Center of Islamic Business and Economic Studies (CIBEST) Model.

Previous research conducted by Bastiar and Bahri (2019) stated that the CIBEST model is a measuring tool for measuring the performance of zakat distribution. Amuda and Embi (2016) argue that measuring the impact of zakat helps ensure the accuracy of using zakat on mustahiq. The results of previous research by Sumantri (2018), who used the CIBEST model approach, found that there were changes in the welfare of mustahiq, but this was not significant. Meanwhile, Puskas (2017a) shows that the utilization of zakat has a positive impact on the welfare of mustahiq. Both studies used the same object, namely, the Baznas entity. Measurement of the impact of zakat on mustahiq with objects in LAZ was carried out by Puskas (2020), but the LAZ Baitul Maal Hidayatullah (BMH). Therefore, in this study, the object used was the LAZ BMH entity.

LAZ BMH is one of the LAZs that makes efficient use of zakat. One of the zakat utilization programs carried out by $\mathrm{BMH}$ is assistance with mustahiq through the School of Ibu Hebat program. LAZ BHM channeled the assistance in the form of business capital to the micro business group in Cipayung District, Depok. Program support is also provided in the form of training, mentoring, and supervision. LAZ $\mathrm{BMH}$ did this with the aim that the management of the mustahiq micro business can run well.

To determine the impact of zakat utilization by $\mathrm{BMH}$, it is necessary to measure the impact of zakat. This measurement is essential as a form of accountability in zakat utilization. This is as stated in the 2016-2020 National Zakat Strategic Plan with a target of the number of poor who are alleviated from the poverty line by $1 \%$ each year from the number of poor people or around 280,000 people (Nasir et al., 2016). Meanwhile, based on the 2019 National Zakat Statistics (Baznas, 2019), the number that has been raised has only reached 191,090 people or $68 \%$ of the target. LAZ made the most significant contribution (49\%), followed by Baznas District/City (37.4\%), Baznas (8.2\%), and Baznas Province (4.9\%). 
According to Triyuwono (2001), in principle, the primary responsibility of the entity, in this context, is the zakat management entity, vertically to Allah SWT, which is further translated into horizontal responsibility for humanity and the natural environment (Meldona et al., 2020). Therefore, in this study, the impact of zakat was measured using the CIBEST model. This model is considered relevant because the measurement of the impact of zakat includes both material and spiritual aspects. Therefore, the description in this study consists of an introduction, research method, results, discussion, and conclusion.

\section{RESEARCH METHODS}

This study used a quantitative research design using the CIBEST model. It examines the impact of zakat on mustahiq on material and spiritual aspects. The data were collected through observations and interviews. The instrument used in this study was in the form of a questionnaire. It is distributed to mustahiq households. The population of this study was mustahiq beneficiaries of productive zakat for the School of Ibu Hebat program, as many as 50 mustahiq people. Sampling was performed purposively using the criteria determined by the researcher. These criteria include mustahiq households that actively participate in the school of Ibu Hebat.

To determine the sample size, we use the Slovin formula as follows.

$$
n=\frac{N}{1 \_N e^{2}}
$$

Information:

$\mathrm{n}=$ sample size

$\mathrm{N}=$ population size

$\mathrm{e}=$ the percentage of inaccuracy is due to sampling errors $(10 \%)$

So, the number of samples taken is:

$$
n=\frac{50}{1+(50)(0,1)^{2}}=33,33
$$

Based on the objects and methods used, the variables used in this study consisted of independent variables, namely, productive zakat and dependent variables, namely poverty. From the explanation above, the indicators in this study are illustrated in the table below.

Table 1. Research Indicators

\begin{tabular}{cll}
\hline Research variable & \multicolumn{1}{c}{ Dimension } & \multicolumn{1}{c}{ Indicator } \\
\hline Productive Zakat $(\mathrm{X})$ & $\begin{array}{l}\text { Business Capital, Training, } \\
\text { Assistance, Business supervision to } \\
\text { the mustahiq }\end{array}$ & $\begin{array}{l}\text { Quadrant I: Rich } \\
\text { materially and spiritually }\end{array}$ \\
\hline
\end{tabular}




\begin{tabular}{lll}
\hline Poverty (Y) & Material aspects: household & Quadrant II: Materially \\
income below the poverty line per & poor and spiritually rich \\
capita per month. & Quadrant III: Materially \\
& $\begin{array}{l}\text { Spiritual aspects: prayer, fasting, } \\
\text { zakat, infaq/alms, family } \\
\text { environment, and government } \\
\text { policies }\end{array}$ & $\begin{array}{l}\text { rich and spiritually poor } \\
\text { Quadrant IV: Materially } \\
\text { and spiritually poor }\end{array}$ \\
&
\end{tabular}

Source: Primary data processed (2020)

The welfare measurement used in this study is the CIBEST model. The CIBEST model can measure welfare, including the material and spiritual aspects. The CIBEST model consists of the CIBEST Quadrant and CIBEST Index. In the material poverty line, the approach before and after getting zakat assistance is based on the calculation of the material value (MV). MV is a measurement tool used to determine whether a household is sufficient. According to Beik and Arsyianti (2015), based on the MV measurement in the CIBEST model, it is concluded that a household is in the material category with an income above the MV value. Using the formula explained below,

$$
M V=\sum_{i=1}^{n} P i M i
$$

Information:

MV = Minimum standard of material needs that must be met by households (IDR

or

other currencies) or can be called the Material Poverty Line

$\mathrm{Pi}=$ Prices of goods and services (IDR or other currencies)

$\mathrm{Mi}=$ Minimum amount of products and services needed

The MV used in the study is based on the Depok Poverty Line (GK) material per capita issued by the BPS, which will later be converted to per capita household poverty line per month. Following previous research conducted by (Pratama, 2015), the calculation of the household poverty line is obtained from the multiplication between the poverty line per capita per month and the average size of the household. The average number of households is the ratio of the population to the number of households in the study area. The household poverty line for conditions before receiving zakat funds is based on the 2017 GK Depok, which is IDR556,470 (BPS, 2018). The total population and number of households were $2,254,513$, with 545,065 households.

Average size of household

$$
\begin{aligned}
& =2.254 .513 / 545.065 \\
& =4.3
\end{aligned}
$$

Thus, the household poverty line (MV) before receiving zakat assistance is as follows:

$$
\mathrm{MV}=\mathrm{IDR} 556.470 \times 4.3
$$




\section{$=$ IDR2.281.527}

The household poverty line for the condition after obtaining zakat assistance is obtained by the same calculation using the 2018 GK in the amount of Rp. 615,255 (BPS 2018). The total population and households were 2,330,333 and 539,132 households, respectively. Thus, the household poverty line (MV) after receiving zakat assistance is as follows:

Average size of household

$$
\begin{aligned}
& =2.330 .333 / 539.132 \\
& =4.3
\end{aligned}
$$

Thus, the household poverty line (MV) after receiving zakat assistance is as follows:

$$
\begin{aligned}
\mathrm{MV} & =\mathrm{IDR} 615.255 \times 4.3 \\
& =\mathrm{IDR} 2.645 .597
\end{aligned}
$$

The spiritual poverty line is based on the calculation of spiritual value (SV), which is a measure used to determine whether a household is spiritually sufficient. The measurement of spiritual poverty is based on the ability of a person or family to meet their spiritual needs. If they are unable to do so, they experience spiritual poverty. Fulfillment of spiritual needs was calculated based on the fulfillment standard of five (five variables: the implementation of prayer, zakat, fasting, family/household environment, and government policy). To assess the scores of

\begin{tabular}{|c|c|c|c|c|c|c|}
\hline \multirow{2}{*}{ Variable } & \multicolumn{5}{|c|}{ Likert Scale } & \multirow{2}{*}{$\begin{array}{c}\text { Poverty } \\
\text { Standards }\end{array}$} \\
\hline & 1 & 2 & 3 & 4 & 5 & \\
\hline Salat & $\begin{array}{l}\text { Banned } \\
\text { person } \\
\text { other } \\
\text { Salat }\end{array}$ & $\begin{array}{l}\text { Reject the } \\
\text { concept } \\
\text { Salat }\end{array}$ & $\begin{array}{l}\text { doing } \\
\text { obligatory } \\
\text { prayers } \\
\text { not a routine }\end{array}$ & $\begin{array}{l}\text { Doing } \\
\text { obligatory prayers } \\
\text { routine but no } \\
\text { always } \\
\text { in congregation }\end{array}$ & $\begin{array}{l}\text { Doing } \\
\text { obligatory } \\
\text { prayers } \\
\text { routine } \\
\text { in } \\
\text { congregation } \\
\text { and } \\
\text { sunnah prayer }\end{array}$ & \multirow{4}{*}{$\begin{array}{l}\text { Score } \\
\text { average } \\
\text { for } \\
\text { family } \\
\text { that } \\
\text { in a manner } \\
\text { spiritual } \\
\text { poor } \\
\text { is } 3 \\
(\mathrm{SV}=3)\end{array}$} \\
\hline Fasting & $\begin{array}{l}\text { Banned } \\
\text { person } \\
\text { other } \\
\text { fast }\end{array}$ & $\begin{array}{l}\text { Doing } \\
\text { compulsory } \\
\text { fasting } \\
\text { not full }\end{array}$ & $\begin{array}{l}\text { Doing } \\
\text { compulsory } \\
\text { fasting } \\
\text { not full }\end{array}$ & $\begin{array}{l}\text { Only } \\
\text { doing } \\
\text { compulsory } \\
\text { fasting } \\
\text { fully }\end{array}$ & $\begin{array}{l}\text { Doing } \\
\text { compulsory } \\
\text { fasting } \\
\text { and fasting } \\
\text { sunnah }\end{array}$ & \\
\hline $\begin{array}{l}\text { Zakat and } \\
\text { infaq }\end{array}$ & $\begin{array}{l}\text { Banned } \\
\text { person } \\
\text { other } \\
\text { tithe } \\
\text { and } \\
\text { be active }\end{array}$ & $\begin{array}{l}\text { Reject } \\
\text { zakat and } \\
\text { infaq }\end{array}$ & $\begin{array}{l}\text { Never } \\
\text { even though } \\
\text { once in } \\
\text { a month }\end{array}$ & $\begin{array}{l}\text { Pay } \\
\text { zakat fitrah } \\
\text { and Zakat } \\
\text { treasure }\end{array}$ & $\begin{array}{l}\text { Pay } \\
\text { zakat fitrah, } \\
\text { zakat of } \\
\text { wealth and } \\
\text { infaq/alms }\end{array}$ & \\
\hline $\begin{array}{l}\text { Family } \\
\text { environment }\end{array}$ & $\begin{array}{l}\text { Banned } \\
\text { member } \\
\text { family } \\
\text { worship }\end{array}$ & $\begin{array}{l}\text { Reject } \\
\text { implementati } \\
\text { on } \\
\text { worship }\end{array}$ & $\begin{array}{l}\text { Assume } \\
\text { worship affairs } \\
\text { personal } \\
\text { member } \\
\text { family }\end{array}$ & $\begin{array}{l}\text { Assume } \\
\text { worship affairs } \\
\text { personal } \\
\text { member } \\
\text { family }\end{array}$ & $\begin{array}{l}\text { Build a } \\
\text { family } \\
\text { atmosphere } \\
\text { that supports } \\
\text { worship } \\
\text { together }\end{array}$ & \\
\hline
\end{tabular}
each of these variables according to (Beik and Arsyianti, 2015) Likert scale ranging from 1 to 5 was used.

Table 2. Indicators of Spiritual Needs 


\begin{tabular}{|c|c|c|c|c|c|}
\hline $\begin{array}{l}\text { Government } \\
\text { policy }\end{array}$ & $\begin{array}{l}\text { Prohibit } \\
\text { worship } \\
\text { for each } \\
\text { family }\end{array}$ & $\begin{array}{l}\text { Refuse } \\
\text { worship }\end{array}$ & $\begin{array}{l}\text { Regarding } \\
\text { worship of } \\
\text { private affairs } \\
\text { of the }\end{array}$ & Support worship & $\begin{array}{l}\text { Creating an } \\
\text { environment } \\
\text { conducive to } \\
\text { worship }\end{array}$ \\
\hline
\end{tabular}

Source: Beik and Arsyianti (2015)

\subsection{Quadrant on CIBEST Model}

Based on the MV and SV calculations, each household can be classified into the CIBEST quadrant. If the actual spiritual score of the household is higher than the $\mathrm{SV}$ value and the family income is higher than the MV value, then the household is categorized in quadrant I. Quadrant I is materially and spiritually rich. If the actual spiritual score of the household is higher than the SV value and the income is smaller than the MV value, then the household is categorized as Quadrant II.

Quadrant II is spiritually rich but materially poor. Furthermore, if the actual spiritual score is smaller than the SV value and the household income is higher than the MV value, it is included in the Quadrant III category. Quadrant III is spiritually poor but materially rich. Finally, households that have an actual spiritual score are smaller than SV, and income is lower than MV, so those households fall into the Quadrant IV category. Quadrant IV is spiritually poor and materially poor.

Table 3. Classification of the CIBEST Quadrant

\begin{tabular}{|c|c|c|}
\hline Actual score & $\leq$ Value MV & > Value MV \\
\hline > Value SV & $\begin{array}{l}\text { Rich in Spiritually, Poor in } \\
\text { Materially } \\
\text { (Quadrant II) }\end{array}$ & $\begin{array}{l}\text { Rich in spiritually, Rich in } \\
\text { Materially } \\
\text { (Quadrant I) }\end{array}$ \\
\hline$\leq$ Value SV & $\begin{array}{l}\text { Poor in Spiritually, Poor in } \\
\text { Materially } \\
\text { (Quadrant IV) }\end{array}$ & $\begin{array}{l}\text { Poor in Spiritually, Rich in } \\
\text { Materially } \\
\text { (Quadrant III) }\end{array}$ \\
\hline
\end{tabular}

Source: Beik and Arsyianti (2015)

\section{CIBEST Model Index}

The CIBEST index can be measured after categorizing households into quadrants. This index is a measurement tool that was developed using the CIBEST model. The development of this index was based on the CIBEST quadrant. The CIBEST index was used to calculate the population in each of the CIBEST quadrants. CIBEST index (Beik and Arsyianti, 2015) terdiri dari Indeks Kemiskinan Material (Pm), Indeks Kemiskinan Spiritual (Ps), Indeks Kemiskinan Absolut (Pa), dan Indeks Kesejahteraan (W). Rumus dan uraian masing-masing Indeks CIBEST diuraikan di bawah ini.

\section{a. Welfare Index}

$$
W+P m+P s+P a=1
$$

The welfare index developed by CIBEST seeks to describe the distribution of mustahiq households in Quadrant I or prosperity. In this context, prosperity is a mustahiq household that is materially and spiritually adequate. The welfare index is obtained from the ratio of the number of prosperous mustahiq households with the number of mustahiq households observed. This index has a value of $0-1$. The 
higher the index value, the more prosperous mustahiq households are. The following formula was used to calculate the material poverty index:

Information:

$$
W=\frac{W}{N}
$$

$\mathrm{W} \quad=$ Welfare Index; $0 \leq \mathrm{W} \leq 1$

$\mathrm{W} \quad=$ number of prosperous families (materially and spiritually rich)

$\mathrm{N} \quad=$ number of household samples observed

\section{b. Material Poverty Index}

The material poverty index is used to determine the number of mustahiq households in Quadrant II, or included in material poverty. The material poverty index is obtained from the comparison between the number of material-poor mustahiq households and the total sample of families observed. This index has a value between zero and $0-1$. The smaller the index value, the fewer mustahiq households experience material poverty. The following is the formula for the material poverty index, according to Beik and Arsiyanti (2015).

Information:

$$
P m=\frac{M p}{N}
$$

$\mathrm{Pm}=$ material poverty index $0 \leq \mathrm{Pm} \leq 1$

$\mathrm{Mp}=$ number of families who are materially poor but spiritually rich

$\mathrm{N} \quad=$ number of household samples observed

\section{c. Spiritual Poverty Index}

The Spiritual Poverty Index is used to determine the number of mustahiq households in Quadrant III, or included in spiritual poverty. The spiritual poverty index is obtained by comparing the number of mustahiq households that are spiritually poor with the total sample of families observed. This index has a value between zero and 0-1. The smaller the index value, the fewer mustahiq households experience spiritual poverty. The following are the spiritual poverty index formulas according to Beik and Arsiyanti (2015):

Information:

$$
P S=\frac{S p}{N}
$$

Ps $\quad=$ Spiritual poverty index $0 \leq \mathrm{Pm} \leq 1$

$\mathrm{Sp} \quad=$ The number of spiritually poor families, is materially rich.

$\mathrm{N} \quad=$ number of household samples observed

\section{d. Absolute Poverty Index}

The absolute poverty index is used to determine the number of mustahiq households in quadrant IV, or included in spiritual poverty. The spiritual poverty index is obtained by comparing the number of material-poor mustahiq households with the total sample of families observed. This index has a value between zero and $0-1$. The smaller the index value, the fewer mustahiq households experience spiritual 
poverty. The following formula was used to calculate the material poverty index, according to Beik and Arsiyanti (2015):

Information:

$$
P a=\frac{A p}{N}
$$

$\mathrm{Pa}=$ Absolute poverty index; $0 \leq \mathrm{Ps} \leq 1$

Ap = number of families spiritually and materially poor

$\mathrm{N} \quad=$ number of household samples observed

\section{RESULTS AND DISCUSSION}

\section{Program Profile}

The Amil Zakat Institution (LAZ) Baitul Maal Hidayatullah (BMH) is the National Amil Zakat Institution. BMH was confirmed by the Indonesian Ministry of Religion with Decree No. 425 of 2015, which manages zakat, infaq/alms, and other social humanitarian funds, including waqf, grants, and corporate social responsibility (CSR) funds. Distribution programs cover the fields of education, preaching, social, humanitarian, and national economies.

The vision carried out by LAZ BMH is to become the leading and trusted amil zakat institution, whereas the LAZ BMH mission includes three missions. First, it is an Amil Zakat Institution that is foremost in the collection and focuses on utilization. Second, carry out management of the zakat, infaq/alms funds, following modern management that is transparent and professional. Third, the Ummah was empowered by increasing the quantity, quality of education, and propaganda.

One of the economic empowerment programs in the LAZ BMH is the School of Ibu Hebat. The School of Ibu Hebat began in September 2018. The School of Ibu Hebat is an economic empowerment program that focuses on MSME capital in the Cipayung Subdistrict, Depok. The background was established by the School of Ibu Hebat program because she saw that many mothers struggled to support their families. After all, their husbands died; they were terminated from work, were sick, and were unable to work anymore. Some even left her husband. There is also a mother who is willing to work to help her husband meet their daily needs. Not a few of them are only educated in junior and senior high schools and do not have other skills. The hand does not have any business capital.

Based on these conditions, LAZ BMH was present through the MAPAN (Independent Leading) program, one of the sub-programs being the School of Ibu Hebat. Aiming to raise the dignity and status of mothers through training and enhancing life skills, capital support, and group-based economic development while helping to reduce poverty and unemployment and strengthen the mental and spiritual side.

In the School of Ibu Hebat program, each member is divided into several MSME groups in the Cipayung Subdistrict, Depok, who experience difficulties accessing business capital. The School of Ibu Hebat program aims to improve the regional 
economy, especially in the Cipayung Subdistrict, Depok. This program consists of five groups in each village in Cipayung, namely Cipayung Village, Cipayung Jaya Village, Ratu Jaya Village, Pondok Jaya Village, and Bojong Village Pondok Terong. Each group consisted of approximately ten people, each consisting of six people from the Cipayung District MSME community and four people from the poor and widows.
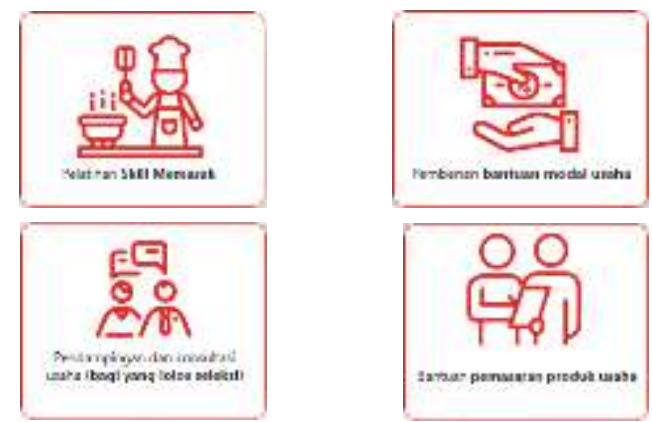

Figure 1. Forms of School of Ibu Hebat Program Activities Source: BMH (2020)

In the picture above in the School of Ibu Hebat program, each group receives business capital assistance in the form of production equipment worth 4 million rupiahs, which is useful for supporting the sustainability of MSMEs. The School of Ibu Hebat program focuses on the sale of processed Siomay Brain Meatball (BSO) products. Before running the business, the members are given Cooking Skill training every week on how to manage BSO products so that they can be applied directly to the processing of the product.

Moreover, when running a BSO business, each group produces at least once a week. In addition to cooking skills and training, the School of Ibu Hebat program, which is managed directly by $\mathrm{BMH}$, also conducts business mentoring and supervision every month for each MSME group. Assistance is carried out, such as brand creation, product promotion, and product marketing. Furthermore, the form of supervision carried out by the School of Ibu Hebat is direct monitoring from the $\mathrm{BMH}$ on the development of the MSME group in running a business.

\section{Characteristics of Respondents}

Respondent characteristics illustrate the demographic conditions of mustahiq beneficiaries of the School of Ibu Hebat program. As shown in Table 4, the total number of members of the School of Ibu Hebat program was 35 (100\%). From the other male gender by 0 people or by 0 percent. Based on age, it is known that the majority of members of the School of Ibu Hebat program are in the productive age of 15-64 years. At vulnerable ages $15-40$ by nine people or 26 percent, and vulnerable ages 41-64 years by 24 people or by 68 percent. At the age of unproductive, but still working for more than 64 years by two people or by six percent.

Table 4. Characteristics of the School of Ibu Hebat Members 


\begin{tabular}{|c|c|c|c|}
\hline Characteristics & Classification & Amount & Percentage \\
\hline \multirow{2}{*}{ Gender } & Male & 0 & 0 \\
\hline & Female & 35 & 100 \\
\hline \multirow{3}{*}{ Age } & $15-40$ & 9 & 26 \\
\hline & $41-64$ & 24 & 68 \\
\hline & $>64$ & 2 & 6 \\
\hline \multirow{2}{*}{ Marital status } & Married & 27 & 77 \\
\hline & Widow & 8 & 23 \\
\hline \multirow{6}{*}{ Level of education } & Never & 2 & 6 \\
\hline & Elementary School & 2 & 6 \\
\hline & Junior High School & 6 & 17 \\
\hline & Senior High School & 20 & 57 \\
\hline & Diploma & 2 & 6 \\
\hline & Bachelor & 3 & 8 \\
\hline \multirow{3}{*}{ The number of dependents } & $1-3$ & 8 & 23 \\
\hline & $4-6$ & 25 & 71 \\
\hline & $>6$ & 2 & 6 \\
\hline \multirow{5}{*}{ Profession } & Labor & 3 & 8 \\
\hline & Employee & 6 & 17 \\
\hline & Trader & 14 & 40 \\
\hline & Farmer & 2 & 6 \\
\hline & Entrepreneurs & 10 & 29 \\
\hline
\end{tabular}

Source: Primary data processed (2020)

Based on marital status, 27 people were married or 77 percent, while widowed members comprised eight people or 23 percent. Based on the level of education, there are two people, or as much as $6 \%$, have never felt a level of education. At the SD level, there were two people (6\%); at the SMP level, there were six people $(17 \%)$, at the senior secondary level there were 20 people $(57 \%)$, and at the D1 level there were two people (6\%). At the S1 level, there are three people or eight percent.

Based on the number of dependents, the majority have dependents of 4-6 people with 25 people or 71 percent, dependents with 1-3 people amounting to 8 people or 23 percent, dependents with more than 6 amounted to two people or 6 percent. Then, based on the majority of jobs as traders and entrepreneurs, with 14 people or 40 percent as traders and ten people or 40 percent work as entrepreneurs, then those who work as employees are six people or 17 percent. Moreover, the rest worked as farmers and laborers, for farmers amounting to two people or by six percent, and for workers standing to three people or by eight percent.

\section{Data Analysis}

Data analysis included the normality test and paired t-test. The normality test (Aryani and Rachmawati, 2019) aims to test whether in a regression model, the dependent variable, independent variable, or both have a normal distribution. The normality test results indicated the significance value of household income before receiving zakat assistance (Before) of 0.163 and for the significance value of household income after receiving zakat assistance (After) of 0.241. In making 
decisions, if the significance value is higher than the real level of 0.05 , the research data are usually distributed. Moreover, if the significance value was less than the actual level of 0.05 , the research data were distributed abnormally.

From the data values in Table 5, it can be concluded that the income data before and after receiving zakat assistance. It is typically distributed because the significance value of household income before receiving zakat assistance before is 0.163 . Moreover, the significance value of household income after receiving zakat assistance (after) was 0.241 , which was greater than 0.05 .

Table 5. Shapiro-Wilk Normality Test

\begin{tabular}{llllllll}
\hline & \multicolumn{3}{c}{ Kolmogorov-Smirnova } & \multicolumn{3}{c}{ Shapiro-Wilk } \\
\cline { 2 - 7 } & Statistic & f & Sig. & Statistic & f & Sig. \\
\hline Before & 0.126 & 5 & 0.176 & 0.955 & 5 & 0.163 \\
\hline After & 0.144 & 5 & 0.065 & 0.961 & 5 & 0.241 \\
\hline
\end{tabular}

Source: Primary data processed (2020)

\section{Paired T-Test}

Based on Table 6, an illustration is obtained that the average household income before receiving zakat assistance is IDR2.381.428. The average household income after receiving zakat assistance was IDR2.835.714. This shows that there was an increase in household income after receiving zakat assistance amounting to IDR454.286.

Table 6. Average Household Income of Mustahiq

\begin{tabular}{rlllrr}
\hline \multicolumn{6}{c}{ Paired Samples Statistics } \\
\hline & Mean & N & Std. Deviation & Std. Error Mean \\
\hline \multirow{2}{*}{ Pair 1 } & Before & 2381428.57 & 35 & 621441.128 & 105042.723 \\
\cline { 2 - 6 } & After & 2835714.29 & 35 & 643013.52 & 108689.122 \\
\hline
\end{tabular}

Source: Primary data processed (2020)

The average household income mustahiq before the provision of zakat (IDR2.381.428) above the material poverty line in Depok in 2017, which is IDR $2,281,527$, with a difference of IDR99.901, whereas the average household income of mustahiq after receiving zakat assistance in the amount of IDR2.835.714 is above the material poverty line in Depok in 2018, which is IDR2.645.597, with a difference of IDR190.117.

\subsection{Analisis Kuadran CIBEST}

Based on the table above in quadrant I, households of mustahiq welfare experienced an increase of four households from before receiving zakat assistance, namely 19 people to 23 people after receiving zakat assistance. In quadrant II, material-poor mustahiq households experienced a reduction of four people who moved to 
quadrant I, before receiving zakat assistance, 16 people mustahiq, and after receiving zakat assistance from 12 people. Furthermore, quadrants III and IV, before and after receiving zakat assistance, no mustahiq households experience spiritual poverty or absolute poverty.

Table 7. CIBEST Quadrant for Mustahiq LAZ Baitul Maal Hidayatullah

\begin{tabular}{|l|c|c|}
\hline \multirow{2}{*}{ Quadrant } & \multicolumn{2}{|c|}{ Number of Mustahiq Households } \\
\cline { 2 - 3 } & $\begin{array}{c}\text { Before There Is Zakat } \\
\text { Assistance }\end{array}$ & After Zakat Assistance \\
\hline Quadrant I (Prosperous) & 19 & 23 \\
\hline Quadrant II (Poor Material) & 16 & 12 \\
\hline Quadrant III (Poor Spiritual) & 0 & 0 \\
\hline Quadrant IV (Absolute Poor) & 0 & 0 \\
\hline
\end{tabular}

Source: Primary data processed (2020)

\section{CIBEST Index Analysis}

Table 8. CIBEST index for Mustahiq LAZ Baitul Maal Hidayatullah

\begin{tabular}{lccc}
\hline CIBEST index & $\begin{array}{c}\text { Index Value Before } \\
\text { There Is Zakat } \\
\text { Assistance }\end{array}$ & $\begin{array}{c}\text { Index Value } \\
\text { After Zakat } \\
\text { Assistance }\end{array}$ & $\begin{array}{c}\text { The difference in } \\
\text { Change (percent) }\end{array}$ \\
\hline Material Poverty Index & 0.457 & 0.342 & 11.5 \\
\hline Spiritual Poverty Index & 0 & 0 & 0 \\
\hline Absolute Poverty Index & 0 & 0 & 0 \\
\hline Welfare Index & 0.542 & 0.657 & $(11.5)$ \\
\hline
\end{tabular}

Source: Primary data processed (2020)

\section{Mustahiq Household Welfare}

The Mustahiq household welfare index at the time of the condition before the assistance of zakat funds and guidance has a value of 0.542 or equivalent to 54.2 percent. This means that only 54.2 percent of households must be able to meet their material needs and spiritual needs at the same time or be in a prosperous condition before the provision of zakat funds and guidance.

After the provision of zakat funds and guidance, the mustahiq household welfare index increased from 0.115 to 0.657 . This illustrates that after the provision of zakat funds and guidance, mustahiq households that can meet their material and spiritual needs simultaneously increased by 11.5 percent to 65.7 percent. Increasing the welfare of mustahiq households is in line with existing theories where mustahiq households that include Islamic values in their activities will lead to the fulfillment of basic needs that contain maslahah.

\section{Material Poverty Index}

The value of the material poverty index before zakat assistance is 0.457 , which means that 45.7 percent of mustahiq households are below the poverty line before zakat assistance. After obtaining zakat assistance, the index value dropped to 0.342 . 
This indicates that the material poverty experienced by households must be reduced by 11.5 percent. The decline in the value of the material poverty index is influenced by the assistance of the zakat fund provided by the BMH. This is in line with the research of Abdullah et al. (2015), who found the effectiveness of zakat in alleviating poverty and inequality in Pakistan.

In this study, BMH channeled a productive zakat fund to increase MSME business capital, which is divided into several groups. Members acknowledge that before the assistance of zakat, there was a lack of capital. After productive zakat assistance, it is easier to obtain JVC. In addition to providing material assistance, LAZ Baitul Maal Hidayatullah also provides guidance and assistance to these mustahiq households in running their businesses.

\section{Spiritual Poverty Index}

Spiritual Poverty Index Analysis of Mustahiq Households in Quadrant III: No household experiences spiritual poverty. This shows that the productive zakat given to mustahiq does not influence the spiritual aspect. The spiritual condition of the mustahiq before and after getting a productive zakat is still the same. Of course, this is not in line with the meaning of zakat, which is to grow and develop.

Therefore, it is essential for the LAZ BMH as a manager to increase assistance to mustahiq, especially in the spiritual aspect. This result is different from previous research by Puskas (2017b), who found that the average spiritual mustahiq score increased from 3.84 4.21. For this reason, it is essential to improve the quality of program planning and increase the effectiveness of mentoring for mustahiqs.

\section{CONCLUSION}

Zakat is a pillar of Islam that is obligatory for the implementation of Muslims. The requirements that must be met are reaching the nisab. Zakat needs to be appropriately managed as a principal act of worship. In Indonesia, zakat management is carried out by zakat management entities consisting of the National Board of Zakat (Baznas), Baznas Province, Baznas Regency/City, and Amil Zakat Institutions (LAZ). One of the LAZs that contributed significantly to the collection and distribution of zakat is the LAZ Baitul Maal Hidayatullah (BMH).

This study measured the impact of zakat on the welfare of mustahiq using the CIBEST Model on mustahiq managed by LAZ BM. Based on this research that has been done, it was found that the mustahiq household welfare index value increased by 11.5 per cent. The increase in the welfare index comes from the material aspect. In terms of material, productive zakat succeeded in reducing material poverty by 11.5. However, the zakat assistance provided does not have a significant effect on poverty alleviation.

In the spiritual aspect, productive zakat has not been able to increase the value of the welfare index because the index value before and after being given productive 
zakat has remained the same. Therefore, as a form of accountability both vertically to Allah SWT and horizontally to stakeholders, it is essential to optimize assistance to mustahiq so that the productive zakat that is distributed can increase the welfare index in the material and spiritual aspects.

Based on the description above, it can be said that changes in the conditions of mustahiq before and after receiving assistance are in line with the objectives of zakat management, namely, to increase the benefits of zakat to realize community welfare and poverty alleviation. This is also in line with the meaning of zakat, which is to grow and develop. Therefore, assistance to mustahiq needs to be optimized so that productive zakat can positively and significantly affect changing the conditions of the mutahik to munfiq and muzaki. Thus, the School of Ibu Hebat Program held by LAZ BMH has not significantly impacted because only four mustahiq households or 11.5 per cent, have left the poverty zone.

\section{REFERENCES}

Abdullah, N., Derus, A. M., \& Al-Malkawi, H. A. N. (2015). The effectiveness of zakat in alleviating poverty and inequalities a measurement using a newly developed technique. Humanomics, 31(3), 314-329. https://doi.org/10.1108/H-02-2014-0016

Ahmed, B. O., Johari, F., \& Wahab, K. A. (2017). Identifying the poor and the needy among the beneficiaries of zakat need for a zakat-based poverty threshold in nigeria. International Journal of Social Economics, 44(4), 446458. https://doi.org/10.1108/IJSE-09-2015-0234

Al Qardawi, Y. (2000). Fiqh Al Zakah: A Comparative Study (Vol. I). Centre for Research in Islamic Economics King Abdulaziz University, Ministry of Higher Education Kingdom of Saudi Arabia.

Amuda, Y. J., \& Embi, N. A. C. (2016). Creation of Company through Zakat Funds for Sustainability of Malaysian Asnaf With Reference to Shari'ah Justification. Am-Euras. J. Agric. \& Environ. Sci, 16(5), 1008-1017. https://doi.org/10.5829/idosi.aejaes.2016.16.5.12957

Aryani, D. S., \& Rachmawati, Y. (2019). Tipologi Kemiskinan di Kota Palembang dengan Menggunakan Model Cibest. Jurnal Ilmiah Ekonomi Global Masa Kini, $\quad$ 10(02), 93-98. https://doi.org/http://dx.doi.org/10.35908/jiegmk.v10i2.844

Aziz, M. (2015). Regulasi Zakat Di Indonesia; Upaya Menuju Pengelolaan Zakat yang Profesional. Tafaqquh: Jurnal Penelitian Dan Kajian Keislaman, 3(1), 36-65. https://doi.org/10.36835/hjsk.v4i1.506

Bahri S., A. (2014). Etika Konsumsi Dalam Perspektif Ekonomi Islam. HUNAFA: $\begin{array}{llll}\text { Jurnal Studia } & \text { Islamika, }\end{array}$ https://doi.org/10.24239/jsi.v11i2.360.347-370

Bastiar, Y., \& Bahri, E. S. (2019). Model Pengukuran Kinerja Lembaga Zakat di Indonesia. ZISWAF: Jurnal Zakat Dan Wakaf, 6(1), 43. https://doi.org/10.21043/ziswaf.v1i1.5609 
Baznas. (2019). Statistik Zakat Nasional 2019 (National Zakat Statistics 2019). In Baznas. Baznas.

Beik, I. S., \& Arsyianti, L. D. (2015). Construction of Cibest Model As Measurement of Poverty and Welfare Indices From Islamic Perspective. AlIqtishad: Journal of Islamic Economics, 7(1), 87-104. https://doi.org/10.15408/ijies.v7i1.1361

Beik, I. S., \& Arsyianti, L. D. (2016). Measuring Zakat Impact on Poverty and Welfare Using Cibest Model. Journal of Islamic Monetary Economics and Finance, 1(2), 141-160. https://doi.org/10.21098/jimf.v1i2.524

Chaniago, S. A. (2015). Pemberdayaan Zakat dalam Mengentaskan Kemiskinan. Jurnal Hukum Islam, 13(47), 47-56.

Ganiyev, A., \& Umaraliev, S. (2020). The Role of Zakat in the Early Stages of the Islamic Civilisation. EPRA International Journal of Multidisciplinary Research (IJMR)-Peer Reviewed Journal, 6(6), 441-444. https://doi.org/10.36713/epra2013

Hakim, B. R. (2016). Analisis Terhadap Undang-Undang Nomor 23 Tahun 2011 Tentang Pengelolaan Zakat (Perspektif Hukum Islam). Syariah Jurnal Hukum Dan Pemikiran, 15(2), 155-166. https://doi.org/10.18592/syariah.v15i2.552

Khumaini, S. (2019). Analysis of the Effect of Empowering Productive Zakat Funds on Welfare of the People. JESI (Jurnal Ekonomi Syariah Indonesia), 8(2), 81. https://doi.org/10.21927/jesi.2018.8(2).81-88

Kurniawan, M. Z., Ula, M. F., \& Setyawan, A. (2020). Pengaruh Zakat Produktif, Manajemen Usaha, dan Pendampingan Terhadap Perkembangan Usaha Mikro Mustahik di LAZNAS LMI Unit Layanan Blitar. BISEI: Jurnal Bisnis Dan ..., 05(April), $30-39$. http://ejournal.unhasy.ac.id/index.php/bisei/article/view/1120

Kusuma, K. A. (2016). Zakah index : Islamic economics '. Indonesian Journal of Islam and Muslim Societies, 6(2), 273-301. https://doi.org/10.18326/ijims.v6i2.273-301

Meldona, Riska, N. A., Rochayatun, S., \& Nurdin, F. (2020). Corporate Social Responsibility Disclosure Through Sharia Enterprise Theory. 135(Aicmbs 2019), 171-179. https://doi.org/10.2991/aebmr.k.200410.026

Mujiatun, S. (2018). Model of professional zakat management in indonesia. International Journal of Economics, Business and Management Research, 2(4), 80-90.

Nafiah, L. (2015). Pengaruh Pendayagunaan Zakat Produktif Terhadap Kesejahteraan Mustahiq Pada Program Ternak Bergulir Baznas Kabupaten Gresik. El-Qist, V(01), 307-321.

Nasir, M., Bahri, E. S., Purwakananta, M. A., Tohir, K. M., Adinugroho, A. S., Qasim, F., Hidayat, D., Andriadi, Sidik, R., Hambali, A., \& Hanum, K. (2016). Rencana Strategis Zakat Nasional 2016-2020. In Baznas. Baznas. http://pid.baznas.go.id/rencana-strategis-2016-2020/

Pratama, Y. C. D. Y. Q. 2000. (2015). Peran Zakat Dalam Penanggulangan Kemiskinan (Studi Kasus : Program Zakat Produktif Pada Badan Amil Zakat Nasional). The Journal of Tauhidinomics, 1(1), 93-104. https://doi.org/10.15408/thd.v1i1.3327 
Puskas. (2017a). Dampak Zakat terhadap Kesejahteraan Mustahik di Indonesia: Evaluasi Program Zakat Produktif Baznas. In Baznas. https://doi.org/10.1088/1751-8113/44/8/085201

Puskas. (2017b). Kaji Dampak Penyaluran Zakat Baznas Terhadap Kesejahteraan Mustahik Tahun 2016.

Puskas. (2020). Indeks Zakat Nasional \& Kaji Dampak Zakat LAZ 2019. In Baznas (Issue March).

Riyaldi, M. H. (2017). Kedudukan dan prinsip pembagian zakat dalam mengatasi permasalahan kemiskinan (analisis pandangan yusuf qardhawi). Jurnal Perspektif Ekonomi Darussalam, 3(1), 17-27. https://doi.org/10.24815/jped.v3i1.6989

Satori Ismail, A., Farid Mas'udi, M., Bahri, E. S., Halim, I., Tajang, M. N., Qasim, F., Hambali, A., \& Erianton, P. (2018). Fikih Zakat Kontekstual Indonsia. BAZNAS.

Septiandani, D., \& Shomad, A. (2017). The Principles of Zakat and Tax Upon the Time of Rasulullah SAW. Hang Tuah Law Journal, 1(1), 90. https://doi.org/10.30649/htlj.v1i1.11

Sumantri, R. (2018). Efektifitas Dana Zakat Pada Mustahik Zakat Community Development Sumatera Selatan Dengan Pendekatan Cibest. I-ECONOMICS: A Research Journal on Islamic Economics, 3(2), 209. https://doi.org/10.19109/ieconomics.v3i2.1688

Taufiq, I. F., Kusnendi, \& Nurasyiah, A. (2018). The Effect of Productive Zakat, Business Experience, and Mentoring on Farmers' Revenues (Survey on Lumbung Desa Program by Sinergi Foundation in Cibaeud Village, Cigalontang District, Tasikmalaya Regency). International Journal of Zakat, 3(3), 55-67. https://doi.org/10.37706/ijaz.v3i3.95

Triyuwono, I. (2001). Metafora Zakat dan Shari'ah Enterprise Theory Sebagai Konsep Dasar dalam Membentuk Akuntansi Syari'Ah. Jurnal Akuntansi Dan Auditing Indonesia, 5(2), 131-145.

Yusuf, M. B. O., \& Derus, A. M. (2013). Measurement model of corporate zakat collection in Malaysia: A test of diffusion of innovation theory. Humanomics, 29(1), 61-74. https://doi.org/10.1108/08288661311299321 